\section{Tissue Respiration and Transamination in Cold Stress}

In the phylogenetic evolution of thermoregulation, under cold stress, liver and kidney tissues of poikilothermal toads show a marked increase in succinate and ascorbate oxidation to 105.150 per cent of that at $30^{\circ} \mathrm{C}$. ; in stenothermal hirds, there is an increaso of only 22-35 per cent, while in the homoiothermal rat there is a depression of 21-27 per cent. This indicates that in the rat the depression of respiration is greater in flavoprotein or preflavoprotein systems than in the cytochromes, while in the toad and bird the augmentation of respiration by cytochrome system is $1 \cdot 2-1 \cdot 3$ times greater than in the flavoprotein or preflavoprotein systems ${ }^{1}$. An attempt has bcen made in the prosent work to locate the nature of the evolution of oxidative enzymes in the preflavoprotein systems and also to indicate the naturo of changes in oxygen consumption with amino-acid substrates and transamination in these systems. rogulation, flavoprotein and cytochrome systems were evolved oarlier in the poikilotherms and in the stenothermal birds and the preflavoprotein systems wore evolved much later in the homoiothermal mammals. The oxygen consumption with aminoroid substrate undor cold stress increases in rat tissues and only in the liver of toad and bird, but the kidney tissues of the two latter species show a very marked depression in oxygen consumption. In cold stress, tho transamination reaction is, howevor, increased in both liver and kidney of all three species cxamined. Cold stress is known to stimulate the secretion of thyroid hormone, and the possible role of this hormone on the preferential oxidation of aminoacid in the liver in contrast to kidney of toard and pigeon or the role of pyridoxine on amino-acid oxidationt has not been determined in the present investigation. These results suggest that although transamination reactions have evolved quite early in the phylogenetic scale, amino-acid oxidation in the

Table 1. The $Q O_{2} \mathrm{~N}$ (oxygen consumption in $\mu l . / \mathrm{mgm}$. nitrogen per hr.) of liver and kidney homogenates of rats, pigeons and toads at $25^{\circ} \mathrm{C}$. (II) and and thosc exposed to $0^{\circ} \mathrm{C}$. for $2 \frac{1}{2}$ hr. (cold) with $K$ rebs's cycle oxidation pyruvate substrate (I), with $0 \cdot 2 \cdot M$ sodium aspartate silbstrate (II) and transamination capacity expressed as $\mu$ gm. pyruvate formed by decarboxylation of oxaloacetale (ref. 3 ) after $30-m i n$. reaction per hr. group

\begin{tabular}{|c|c|c|c|c|c|c|c|c|c|}
\hline \multirow[b]{2}{*}{ Subject } & \multirow[b]{2}{*}{ Reaction } & \multicolumn{4}{|c|}{ Liver } & \multicolumn{4}{|c|}{ Kidney } \\
\hline & & Control & Cold & $\begin{array}{l}\text { Chamge } \\
\text { (per cent) }\end{array}$ & $\mu$ value & Control & Cold & $\begin{array}{l}\text { Ohangc } \\
\text { (per cent) }\end{array}$ & $\mu$ vialue \\
\hline Rat & $\begin{array}{l}\text { II } \\
\text { III }\end{array}$ & $\begin{array}{r}24 \cdot 6 \pm 2 \cdot 8 \\
27 \cdot 4 \pm 2 \cdot 5 \\
377 \cdot 1 \pm 3 \cdot 6\end{array}$ & $\begin{array}{r}20.9 \pm 1.8 \\
45.9 \pm 2.1 \\
578.4 \pm 3.7\end{array}$ & $\begin{array}{r}\ldots 15 \cdot 1 \\
+67 \cdot 6 \\
+53.4\end{array}$ & $\begin{array}{r}32 \pm 7 \\
268+15 \\
221 \pm 5\end{array}$ & $\begin{array}{r}36 \cdot 0 \pm 2.4 \\
44.7 \pm 2.9 \\
387.8 \pm 3 \cdot 1\end{array}$ & $\begin{array}{r}29 \cdot 3 \pm 1 \cdot 7 \\
74 \cdot 0 \pm 2 \cdot 5 \\
501 \cdot 0 \pm 3 \cdot 1\end{array}$ & $\begin{array}{l}-18 \cdot 6 \\
+65 \cdot 5 \\
+29.2\end{array}$ & $\begin{array}{l}180 \div 13 \\
259 \pm 12 \\
132 \pm 6\end{array}$ \\
\hline Toar & $\begin{array}{r}\text { I } \\
\text { II } \\
\text { III }\end{array}$ & $\begin{array}{r}29 \cdot 4 \pm 2 \cdot 6 \\
33 \cdot 1 \pm 2 \cdot 1 \\
415 \cdot 6 \pm 5 \cdot 6\end{array}$ & $\begin{array}{r}32 \cdot 7+1 \cdot 2 \\
59 \cdot 5 \pm 2 \cdot 6 \\
557 \cdot 9 \pm 8.4\end{array}$ & $\begin{array}{r}+11 \cdot 3 \\
+70 \cdot 7 \\
+\quad 34.3\end{array}$ & $\begin{array}{r}58 \pm 12 \\
303 \pm 12 \\
151 \pm 7\end{array}$ & $\begin{array}{r}57 \cdot 7 \pm 2 \cdot 8 \\
117 \cdot 4 \pm 4 \cdot 3 \\
510 \cdot 4 \pm 5 \cdot 4\end{array}$ & 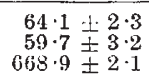 & $\begin{array}{l}+10 \cdot 9 \\
+49 \cdot 1 \\
+31.1\end{array}$ & $\begin{array}{r}54 \pm 10 \\
347 \pm 14 \\
140 \pm 2 \cdot 5\end{array}$ \\
\hline Pigeon & $\begin{array}{l}\text { I } \\
\text { II } \\
\text { III }\end{array}$ & $\begin{array}{r}89 \cdot 0 \pm 2 \cdot 4 \\
62.4 \pm 2 \cdot 6 \\
183.7 \pm 2.9\end{array}$ & $\begin{array}{r}124 \cdot 3+2 \cdot 9 \\
76 \cdot 0 \pm 2 \cdot 7 \\
205 \cdot 5+4 \cdot 2\end{array}$ & $\begin{array}{l}+39 \cdot 6 \\
+21 \cdot 7 \\
+11 \cdot 9\end{array}$ & $\begin{array}{r}172 \pm 13 \\
102 \pm 12 \\
58 \pm 6\end{array}$ & $\begin{array}{r}82 \cdot 3 \pm 2 \cdot 3 \\
82 \cdot 7 \pm 1 \cdot 8 \\
231 \cdot 3 \pm 1 \cdot 7\end{array}$ & $\begin{array}{r}117 \cdot 9 \text { 上 } 3 \cdot 4 \\
63 \cdot 1 \text { 士 } 2 \cdot 3 \\
269 \cdot 5 \pm 3 \cdot 6\end{array}$ & $\begin{array}{l}+43 \cdot 3 \\
-20 \cdot 1 \\
+16 \cdot 5\end{array}$ & $\begin{array}{r}186 \pm 13 \\
116 \pm 12 \\
79 \pm 6\end{array}$ \\
\hline
\end{tabular}

Experiments were carried out on albino rats of either sox weighing $150-200 \mathrm{gm}$. and on pigeons and toads, thirty-two animals of each species being used. These animals were divided into two groups, one group being kept at $25^{\circ} \mathrm{C}$. (control) and the other at $0^{\circ} \mathrm{C}$. in a refrigerator for $2 \frac{1}{2} \mathrm{hr}$. (cold). The animals wero killed, their liver and kidney collected, weighed and homogenized in isotonic cold potassium chloride solution. $0.4 \mathrm{ml}$. of 10 per cent homogenate was used in two Warburg flasks with pyruvate substrates for Krebs cycle oxidation ${ }^{2}$, and in the other two with $0.5 \mathrm{ml}$. of $0.5 \mathrm{M}$ sodium aspartate and $0.2 \mathrm{ml}$. of $0.5 M$ sodium $\alpha$-ketoglutarate for the study of oxygen consumption ${ }^{2}$ and transamination reaction ${ }^{3}$. The gas phaso was air and the oxygen measuremont was made for $30 \mathrm{~min}$. after an equilibrium poriod of $10 \mathrm{~min}$. and, irrmediately after, transamination reaction was studied quantitatively by oxaloacetate measurement after decarboxylation to pyruvate ${ }^{3}$.

The,results are shown in Table 1. The Krebs cycle oxidation system in the rat shows a depression of 15-19 per cont only at the lower ternperature, and the depression is definitely in the preflavoprotein system rather than in the flavoprotein or in the postflavoprotein systems. A very slight augmentation of 11 per cent in toad and of 40 per cent in bird tissue indicates that the augmentation in cold stress lies at the flavoprotein and the postflavoprotein systems rather than in the preflavoprotein systems. This shows that in tho phylogenetic evolution of thermo- kidney has ovolved only to a small extent in the mammals.

I am grateful to Lient.-Col. J. M. Lahiri, director. of veterinary services and animal husbandry, West Bengal, and to Dr. K. C. Mukherjes, principal of this College, for their interest and advice. D. P. SADHE

Department of Physiology and Nutrition, Bengal Veterinary College, Calcutta, 37.

${ }^{1}$ Sadhu, D. P., Quart. J. Exp. Physiol., 44, 357 (1959).

"Umbreit, W. W., Burris, R. W., and Stauffer, J. F., "Manometric Techniques" (Burgess Publishing Co., Minnesota, 1957).

${ }^{3}$ Tonhay, N. E., White, N. G., and Umbreit, W. W., Arch. Biochem., 28, $36(1950)$

- Sadhu, D. P., and Brody, Samuel, Amer. J. Physiol., 151, 342 (1947).

\section{Vitamin A Acid and Hypervitaminosis A}

Although vitamin A acid plays no part in the visual cycle ${ }^{1}$, it is active in the systemic functions of vitamin $\mathbf{A}$ in that it maintains normal growth and skin appearance $e^{1},{ }^{2}$. With Prof. R. A. Morton, we have found (unpublished work) that vitamin A acid also prevents the rise of ubiquinone concentration in rat liver, a characteristic effect of vitarnin A deficiency ${ }^{3}$

We have now compared the offectiveness of vitamin $A$ acid with that of vitamin $A$ (fed in the form of a high-potency fish oil) in producirng hyporvitaminosis A. Thus, two male rats weighing 95 and $105 \mathrm{gm}$. were fed daily $4 \mathrm{mgm}$. vitamin $\mathrm{A}$ acid (as the sodium salt). 